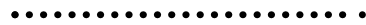

Principles of Exercise Biochemistry 


\section{Medicine and Sport Science}

\section{Vol. 46}

Series Editors

J. Borms Brussels

M. Hebbelinck Brussels

A.P. Hills Brisbane 


\section{Principles of Exercise Biochemistry}

\section{3 rd, revised edition}

Volume Editor

J.R. Poortmans Brussels

51 figures and 19 tables, 2004

KARGER 


\title{
Medicine and Sport Science
}

Founder and Editor from 1969 to 1984: E. Jokl ${ }^{\dagger}$, Lexington, Ky.

\section{Prof. Jacques R. Poortmans}

Chimie Physiologique - ISEPK

Université Libre de Bruxelles

28 Av. P. Heger

B-1000 Brussels

E-Mail: jrpoortm@ulb.ac.be

\author{
Library of Congress Cataloging-in-Publication Data \\ Principles of exercise biochemistry / volume editor, J.R. Poortmans. - 3rd rev. ed. \\ p. ; cm. - (Medicine and sport science, ISSN 0254-5020 ; v. 46) \\ Includes bibliographical references and indexes. \\ ISBN 3-8055-7607-2 (hard cover) \\ 1. Exercise-Physiological aspects. 2. Muscles-Metabolism. 3. Biochemistry. I. \\ Poortmans, J. R. II. Series. \\ [DNLM: 1. Exercise. 2. Biochemistry. 3. Muscles-metabolism. WE 103 P957 2003] \\ QP301.P75 2003 \\ $612^{\prime} .044-\mathrm{dc} 2$
}

Bibliographic Indices. This publication is listed in bibliographic services, including Current Contents ${ }^{\circledR}$ and Index Medicus.

Drug Dosage. The authors and the publisher have exerted every effort to ensure that drug selection and dosage set forth in this text are in accord with current recommendations and practice at the time of publication. However, in view of ongoing research, changes in government regulations, and the constant flow of information relating to drug therapy and drug reactions, the reader is urged to check the package insert for each drug for any change in indications and dosage and for added warnings and precautions. This is particularly important when the recommended agent is a new and/or infrequently employed drug.

All rights reserved. No part of this publication may be translated into other languages, reproduced or utilized in any form or by any means electronic or mechanical, including photocopying, recording, microcopying, or by any information storage and retrieval system, without permission in writing from the publisher.

(C) Copyright 2004 by S. Karger AG, P.O. Box, CH-4009 Basel (Switzerland)

www.karger.com

Printed in Switzerland on acid-free paper by Reinhardt Druck, Basel

ISSN 0254-5020

ISBN 3-8055-7607-2 


\section{Contents}

VII Preface

1 Enzymes, Energy and Endurance. Some Provocative Thoughts Newsholme, E.A. (Oxford)

36 Evolving Concepts of Skeletal Muscle Fibers Noble, E.G.; Rice, C.L.; Thayer, R.E.; Taylor, A.W. (London, Ont.)

62 Molecular Aspects of Muscular Contraction Davis, J.P.; Wahr, P.A.; Rall, J.A. (Columbus, Ohio)

87 High-Energy Phosphates and Muscle Energetics Sahlin, K. (Stockholm)

108 Carbohydrate Metabolism

Greenhaff, P.L. (Nottingham); Hultman, E. (Huddinge); Harris, R.C. (Chichester)

152 Lactate Metabolism during Exercise Gladden, L.B. (Auburn, Ala.)

197 Lipid Mobilization and Utilization Bülow, J. (Copenhagen) 


\section{Protein Metabolism}

Poortmans, J.R. (Brussels)

279 Mechanisms of Muscular Fatigue

Fitts, R.H. (Milwaukee, Wisc.)

\section{Subject Index}




\section{Preface}

A new edition of a book originates mainly because of three major conditions: the previous edition has been sold out, there is a need for updating the information, there are new important developments. These three conditions have been fulfilled for 'Principles of Exercise Biochemistry'. For the last couple of years, one cannot purchase a copy from any bookstore. Since the second edition, 10 years ago, there have been many new publications directed to each chapter of the book. For example, besides qualitative aspects of metabolic regulation, quantitative information has laid to the use (creatine) or disuse (carnitine) of nutrients as ergogenic aids to performance exercise. As well, specific data have been collected on amino acids involved in the energy demand under strenuous and prolonged work. The tremendous development of molecular biology tools into 'exercise biology' has produced an increasing number of papers devoted to what may be called the 'omic' explosion. Genomics, proteomics, and metabolomics are nowadays common terms used to the elucidation of gene function, expression of proteins and comprehensive analysis of all the metabolites in a tissue. The new human genome has arrived and the evolution of broad unbiased biological databases is the compulsory future research and development to integrate the molecule into the whole organism. Would it be a Pandora's box or an Aladdin's cave? To get the appropriate answer, the reader will most probably have to wait for the 4th edition of this book! At least, the last discoveries tell us that the skeletal muscle is sending metabolite signals to other tissues to promote the delivery of indispensable fuels for sustained contractions.

The present edition follows the new concepts of applied biochemistry which have emerged recently in the scientific literature. Instead of introducing 
'basic concepts of metabolic regulation' Newsholme leads the reader to provocative thoughts on enzyme action. The last editions were lacking any precise information on lactate which was often considered a waste product. A new chapter by Gladden will fill in the missing gap. However, despite its interest, we had to remove one previous chapter (Exercise and Metabolic Disorders). This is due to the strict number of pages to be edited and to the marginal interest of this specific topic, not to the quality of the contributors.

Again, we want to emphasize the enthusiastic assistance of S. Karger AG (Basel) in promoting this new edition. Among those more specifically involved, we acknowledge the permanent and vigilant collaboration of Frances Green who willingly (and patiently) and constantly gave us the 'do and don't' information over the whole publication procedure. Last, but not least, the merit of this book is more related to the high standing of its authors and publisher than to the willingness of the editor!

Jacques R. Poortmans, Brussels 